\title{
Usability issues in Learning Management Systems (LMS)
}

\author{
Maria Isabella de Porto Alegre Muniz ${ }^{\mathrm{a}^{*}}$ and Anamaria de Moraes ${ }^{\mathrm{b}}$ \\ Arts and Design Department, PUC-Rio - Pontifical Catholic University of Rio de Janeiro \\ R. Marquês de São Vicente, 225, Prédio Frings: sala 713F, Gávea, Rio de Janeiro-RJ, Brasil, 22453-900 \\ Cx. Postal: 38097
}

\begin{abstract}
This project is about the usability of Learning Management Systems (LMS), focusing on the specific case of the open source system Moodle. Specifically, this project is about communication and collaboration tools that are used by teachers on the system. This study investigates whether usability problems hamper the use teachers make of these tools. Focused interviews were conducted with professionals working in distance education and the answers of the respondents were subjected to techniques of content analysis in order to obtain data for developing the tools needed to prove the hypothesis.
\end{abstract}

Keywords: usability; human computer interaction; distance education; learning management systems; content analysis

\section{Theme}

This project is about the usability of Learning Management Systems (LMS), focusing on the specific case of the open source system Moodle.

Learning Management Systems allow the publication of online content, the organization of activities for learning and course management from a distance and should be studied from both a pedagogical and technological perspective. Open-source products are increasingly present in this market, driven by growing demand. These systems are maintained and developed by communities of users and used by businesses, educational institutions and teachers in general.

Moodle is an online open source learning management system used by educational institutions, companies and teachers in 211 countries; in Brazil there are 4082 registered Moodle sites [1]. It is based on social constructivism, a pedagogical approach that proposes the construction of knowledge through the negotiation of meanings [2]. The Moodle interface in its standard form provides the following features: authoring tools for content creation, inclusion and organization; users, roles and permissions management; homework proposition, student assessment and course evaluation; interaction, communication and collaboration between students and teachers.

According to research by FGV-EAESP - Escola de Administração de Empresas de São Paulo da Fundação Getúlio Vargas - São Paulo School of Business Administration of the Getúlio Vargas Foundation, courses that encourage some sort of interaction between teachers and students have a lower level of evasion [3]. Distance learning courses created within Learning Management Systems provide tools that allow the use of teaching strategies supported by the interaction and collaboration between students and between teachers and students. However, a study by

- Corresponding authors E-mail: mariaisabellamuniz@gmail.com moraergo@puc-rio.br 
the Núcleo de Tecnologia Educacional para a Saúde da Universidade Federal do Rio de Janeiro - Center for Educational Technology for Health of the Federal University of Rio de Janeiro states that these strategies are still seldom used by teachers [4].

\section{Objective}

To examine the interaction between Learning Management Systems and the user-teacher, finding out how usability problems are creating difficulties in the implementation of strategies supported by interaction and communication, thus contributing to improving the learning environment produced by its means.

\section{Justification}

The use of Learning Management Systems for publishing online material by professional teams of Distance Learning or autonomously by teachers is an increasingly common phenomenon, indicating the relevance of studies on the usability of these systems. Research focus on the teacher user and on the relationship between usability and pedagogical strategies is rare, since usability studies usually focus on the studentuser. This focus is consistent with the literature on distance education and virtual learning environments that highlights the importance of communication and collaboration in teaching strategies appropriate for this type of education.

\section{Hypothesis}

Usability problems in the Moodle interface hamper the use of communication and collaboration tools by the teachers.

\section{Method}

The procedure described below is part of an initial exploration of the hypothesis to obtain data for developing the tools necessary to corroborate it. Nondirective and individual interviews were conducted with participants in the construction and deployment of courses developed for the LMS Moodle.

The answers of the respondents were recorded, transcribed and subjected to techniques of content analysis according to Roger Mucchielli's guidelines for the analysis of responses to open questions.

\subsection{Focused interviews}

Focused interviews have an exploratory objective and are, therefore, non directive, addressing a general theme proposed, but not structured by the interviewer, which is limited to stimulating the interviewee without forcing answers. The individuals interviewed are selected according to a search criterion, and should represent different positions on the issue [5].

Six interviews were conducted with professionals with experience in different roles in the construction and implementation of distance learning courses in different institutions:

Interviewee 1 - tutor and course coordinator

Interviewee 2 - instructional designer and course coordinator

Interviewee 3 - web designer

Interviewee 4 - tutor and instructional designer

Interviewee 5 - instructional designer and course coordinator

Interviewee 6 - tutor

The interviewee was asked to talk freely about "communication and collaboration tools for Learning Management Systems" without any prior structuring by the interviewer.

\subsection{Content analysis}

According to Mucchielli "content analysis is intended to be a method to explore fully and objectively informational data". Mucchielli proposes inventory and categorization of information contained in a document or communication through comprehensive, methodical and quantitative analysis. The analyzed material may be pre-existing or created specifically for the research. The categorization of information can obey an existing system or be made from within the content analyzed [6].

The material collected in the interviews was reduced to pieces of content considered significant for the purposes of research and organized into three main catego- 
ries emanating from the research objectives: "Aims of use", "The interface has good usability" and "There are difficulties in interface use." Subcategories emanate from the actual content of interviews. The content units were also categorized as references to specific tools or interface as a whole.

\section{Results}

Table 1

Content analysis results

\begin{tabular}{|c|c|c|c|c|c|c|c|c|}
\hline & $\begin{array}{l}\text { Interface } \\
\text { as a whole }\end{array}$ & Blog & Chat & $\begin{array}{l}\text { Assignment } \\
\text { Feedback }\end{array}$ & Forum & Messages & Wiki & $\begin{array}{l}\text { Totals for each } \\
\text { category }\end{array}$ \\
\hline Aims of use & $\mathbf{0}$ & $\mathbf{0}$ & 6 & 2 & 16 & 1 & 2 & 27 \\
\hline Promoting integration & & & 2 & & & 1 & & 3 \\
\hline Solution for doubt & & & 1 & & 1 & & & 2 \\
\hline $\begin{array}{l}\text { Analysis and evaluation of student } \\
\text { assignments }\end{array}$ & & & 2 & 2 & 1 & & & 5 \\
\hline Task management & & & 1 & & 4 & & & 5 \\
\hline Discussion & & & & & 3 & & & 3 \\
\hline Offering information & & & & & 3 & & & 3 \\
\hline Exhibition of works from students & & & & & 3 & & & 3 \\
\hline Text production in collaboration & & & & & 1 & & 2 & 3 \\
\hline
\end{tabular}

\begin{tabular}{|l|r|r|r|r|r|r|r|r|}
\hline The interface has good usability & $\mathbf{1}$ & $\mathbf{0}$ & $\mathbf{0}$ & $\mathbf{1}$ & $\mathbf{3}$ & & $\mathbf{1}$ & $\mathbf{1}$ \\
\hline It's good & & & & 1 & & & & $\mathbf{7}$ \\
\hline It's easy to use & 1 & & & & 1 & & 1 & \\
\hline It fulfills its aims & & & & & 2 & & 1 & $\mathbf{3}$ \\
\hline
\end{tabular}

\begin{tabular}{|c|c|c|c|c|c|c|c|c|}
\hline $\begin{array}{l}\text { There are difficulties in interface } \\
\text { use }\end{array}$ & 15 & 2 & 10 & $\mathbf{0}$ & 3 & $\mathbf{0}$ & 6 & 36 \\
\hline $\begin{array}{l}\text { The interface presents difficulties for } \\
\text { the novice user }\end{array}$ & 2 & & & & & & & 2 \\
\hline The interface is complicated & 2 & & & & & & & 2 \\
\hline $\begin{array}{l}\text { There is need to support the use of the } \\
\text { interface }\end{array}$ & 5 & & & & & & & 5 \\
\hline $\begin{array}{l}\text { There are difficulties in the use to } \\
\text { prepare courses }\end{array}$ & 3 & & & & & & & 3 \\
\hline Tools are hardly or not used & 3 & & 2 & & 1 & & 1 & 7 \\
\hline Tool does not fulfill its aim & & 2 & 8 & & 1 & & 5 & 16 \\
\hline The form of tool use is not evident & & & & & 1 & & & 1 \\
\hline
\end{tabular}

\begin{tabular}{|l|r|r|r|r|r|r|r|}
\hline Totals for each tool & $\mathbf{1 6}$ & $\mathbf{2}$ & $\mathbf{1 6}$ & $\mathbf{3}$ & $\mathbf{2 2}$ & $\mathbf{2}$ & $\mathbf{9}$ \\
\hline
\end{tabular}

Universe contains 70 content units 


\subsection{Distribution of content units by main categories}

All units of content were classified into three main categories and counted.

Table 2

Distribution of content units by main categories

\begin{tabular}{|l|c|}
\hline Aims of use & $39 \%$ \\
\hline The interface has good usability & $10 \%$ \\
\hline There are difficulties in interface use & $51 \%$ \\
\hline
\end{tabular}

Universe contains 70 content units

\subsection{Distribution of content units by references to tools}

All units of content were also organized by references to tools.

Table 3

Distribution of content units by references to tools

\begin{tabular}{|l|r|}
\hline Interface as a whole & $23 \%$ \\
\hline Blog & $3 \%$ \\
\hline Chat & $23 \%$ \\
\hline Assignment feedback & $4 \%$ \\
\hline Forum & $31 \%$ \\
\hline Messages & $3 \%$ \\
\hline Wiki & $13 \%$ \\
\hline
\end{tabular}

Universe contains 70 content units

\subsection{Distribution of content units inside the category "Aims of use"}

The units of content under the category "Aims of use" were organized in 8 subcategories. They were also organized by references to tools. The percentages used in those tables consider only the units of content under the category.
Table 4

Aims of use organized by aims

\begin{tabular}{|l|r|}
\hline Analysis and evaluation of student assignments & $19 \%$ \\
\hline Task management & $19 \%$ \\
\hline Promoting integration & $11 \%$ \\
\hline Discussion & $11 \%$ \\
\hline Offering information & $11 \%$ \\
\hline Exhibition of works from students & $11 \%$ \\
\hline Text production in collaboration & $11 \%$ \\
\hline Solution for doubt & $7 \%$ \\
\hline
\end{tabular}

Universe contains 27 content units

Table 5

Aims of use organized by tools

\begin{tabular}{|l|r|}
\hline Forum & $59 \%$ \\
\hline Chat & $22 \%$ \\
\hline Assignment feedback & $7 \%$ \\
\hline Wiki & $7 \%$ \\
\hline Messages & $4 \%$ \\
\hline Blog & $0 \%$ \\
\hline
\end{tabular}

Universe contains 27 content units

\subsection{Variety of aims of use assigned to each tool}

The different aims of use assigned to each tool were counted, regardless of the amount of content units, in order to observe the flexibility of each tool.

Table 6

Variety of aims of use assigned to each tool

\begin{tabular}{|l|r|}
\hline Forum & $88 \%$ \\
\hline Chat & $50 \%$ \\
\hline Assignment feedback & $13 \%$ \\
\hline Wiki & $13 \%$ \\
\hline Messages & $13 \%$ \\
\hline Blog & $13 \%$ \\
\hline
\end{tabular}

Universe contains 8 different aims of use

\subsection{Distribution of content units inside the} category "The interface has good usability" 
The units of content under the category "The interface has good usability" were organized in 3 subcategories.

They were also organized by references to tools. The percentages used in those tables consider only the units of content under the category.

Table 7

References to good usability organized by subcategories

\begin{tabular}{|l|c|}
\hline It's easy to use & $43 \%$ \\
\hline It fulfills its aims & $43 \%$ \\
\hline It's good & $14 \%$ \\
\hline
\end{tabular}

Universe contains 7 content units

Table 8

References to good usability organized by tools

\begin{tabular}{|l|r|}
\hline Forum & $43 \%$ \\
\hline Interface as a whole & $14 \%$ \\
\hline Assignments feedback & $14 \%$ \\
\hline Wiki & $14 \%$ \\
\hline Messages & $14 \%$ \\
\hline Blog & $0 \%$ \\
\hline Chat & $0 \%$ \\
\hline
\end{tabular}

Universe contains 7 content units

\subsection{Distribution of content units inside the category "There are difficulties in interface use"}

The units of content under the category "There are difficulties in interface use" were organized in 8 subcategories. They were also organized by references to tools. The percentages used in those tables consider only the units of content under the category.

Table 9

References to difficulties organized by subcategories

\begin{tabular}{|l|r|}
\hline Tool does not fulfill its aim & $44 \%$ \\
\hline Tools are hardly or not used & $19 \%$ \\
\hline There is need to support the use of the interface & $14 \%$ \\
\hline There are difficulties in the use to prepare courses & $8 \%$ \\
\hline The interface presents difficulties for the novice user & $6 \%$ \\
\hline The interface is complicated & $6 \%$ \\
\hline The form of tool use is not evident & $3 \%$ \\
\hline
\end{tabular}

Universe contains 36 content units
Table 10

References to difficulties organized by tools

\begin{tabular}{|l|r|}
\hline Interface as a whole & $42 \%$ \\
\hline Chat & $28 \%$ \\
\hline Wiki & $17 \%$ \\
\hline Forum & $8 \%$ \\
\hline Blog & $6 \%$ \\
\hline Assignment feedback & $0 \%$ \\
\hline Messages & $0 \%$ \\
\hline
\end{tabular}

Universe contains 36 content units

\section{Results analysis}

More than $50 \%$ of the content units refer to difficulties in using the interface. The references to good usability are few. These figures point to the existence of usability problems for the Moodle interface.

The forum is the tool most often cited, followed by the chat, together accounting for $54 \%$ of the units of content, pointing to the importance of the two tools and perhaps to usability problems, since much of the content units refer to problems.

The aims most often cited relate to the analysis and evaluation of results of student work and task management, together accounting for $38 \%$ of content units, indicating the importance of these activities to the respondents. The cited aims are distributed by the tools chat, forum and assignment feedback, which points to the importance of these tools. The tool forum, with $59 \%$ of citations, seems to dominate the usage scenario.

The forum tool corresponds to $88 \%$ of the aims of use cited by respondents, demonstrating its flexibility and relevance. The chat tool is also widely quoted in relation to aims of use.

The forum has more references to good usability than other tools; the qualities of ease of use and the fulfillment of its aims are assigned to it. However these references are few ( 7 references within a universe of 70 units of content) and therefore do not necessarily indicate good usability.

Most of the reported problems relate to the interface as a whole. Difficulties attributed to a tool specifically refer mostly to the chat and wiki.

The reference to the unfulfilled aims of the tools is the indicator of the interface use difficulties most cited, and the chat, followed by the wiki, has more complaints in this category. The forum has very few references to problems, and this is surprising since its use is very extensive as suggested by the amount of usage objectives assigned to it. 


\section{Conclusions}

The discrepancy between the number of references to good usability and usability issues points to the existence of usability problems for the Moodle interface.

The fact that the reference to the unfulfilled aims of communication and collaboration tools is the indicator of difficulties most often cited points to problems in interaction activities between teachers and students.

The forum and chat tools are the tools most often cited and are also those that have a greater number of aims of use associated with them, which suggests that they are more intensively used. This indicates that the study of their use can be significant for the improvement of the interface.

Chat and wiki tools are associated with difficulties of use, specifically to lack of fulfillment of their aims of use and it is therefore recommended that an assessment should identify and explain instances of failures in its use.

In general the results of content analysis of the interviews suggest that the research hypothesis is valid for conducting a usability study of the Moodle interface.

\section{References}

[1] Moodle, Registered Moodle sites, available in: http://moodle.org/sites/index.php? country=BR, access in Ago 27, 2011.

[2] J. Cole, H. Foster, Using Moodle: teaching with the popular open source course management system. Sebastopol, CA, O'Reilly, 2007, p. 4.

[3] E-learning Brasil (2005), Pesquisa revela índice de evasão em educação superior a distância, available in: http://www.elearningbrasil.com.br/home/noticias/clipping.asp ?id=2173, access in Ago 27, 2011.

[4] M. B Espíndola, T. R Giannella, M. Struchiner, Análise de ambientes virtuais de aprendizagem construídos por professores universitários da área de ciências e da saúde. In: Encontro Nacional de Pesquisa em Educação em Ciências, 6., 2007, Florianópolis. Annals... available in: http://www.fae.ufmg.br/abrapec/viempec/viempec/CR2/p659. pdf, access in Jul 29, 2010.

[5] M. Thiollent, Crítica metodológica, investigação social e enquete operária, Polis, São Paulo, 1980, pp. 84-87.

[6] R. Mucchielli, L'analyse de contenu, 8th edition, ESF, Paris, 1998, pp. 23-25. 